International Journal of Business and Management Review

Vol.6, No.3, pp.91-100, April 2018

Published by European Centre for Research Training and Development UK (www.eajournals.org)

\title{
AN ANALYSIS OF EMPLOYEE DEVELOPMENT SYSTEM TO WORKING ACHIEVEMENT IN OBTAINING GET PROFIT AT FA. PMH (FIRMA PERSATUAN MOTOR HORAS), MEDAN, INDONESIA
}

\author{
Hotnida Sirait ${ }^{1}$, Daulat Sihombing ${ }^{1}$, Marion Sibarani ${ }^{2}$ and \\ Chainar Ellyria Tobing ${ }^{2}$
}

\author{
${ }^{1}$ Economy Faculty, Indonesia Methodist University (UMI), Medan, Indonesia \\ ${ }^{2}$ Economy Faculty, Darma Agung University (UDA), Medan, Indonesia
}

\begin{abstract}
Skilled employee can be obtained either in company or out company. If we choose employee from out of company, we will need big expense. Therefore it is possible to use the employee that is exist in the company, by making developing techiques such as coaching based on duty given by company and thing that can increase employee's achievement and desire. Basically Fa.P.M.H. Medan has run the development or education and train, but the number of developed employee is few. In participant selection of employee development, company is less objective. The development of employee's achievement in facing the obstacle is many employees that have followed education and train placed in good place and less in getting company's appreciation.
\end{abstract}

KEYWORDS: Employee; Working Achievement; Profit

\section{INTRODUCTION}

More science increases including improvement in management science, the company must adjust employee's capability in achieving the purpose. The purpose can be achieved by optimizing use of human resource owned by the company especially labor as main implementor by using intelligence and creativity owned to combine factor of production, such as financial capital, land, technology and labor as persons functioning to manage the company. This case has important role to realize company's aim especially if used employee is having achievement in field of operational and managerial.

The purpose of company can be achieved well if the company uses competent employee. Skilled employee can be obtained either in company or out company. If we choose employee from out of company, we will need big expense. Therefore it is possible to use the employee that is exist in the company, by making developing techiques such as coaching based on duty given by company and thing that can increase employee's achievement and desire.

In this case the discussion is employee development where productivity of employee is influenced by related various factors both company environment and government policy such as: education, skill, discipline, attitude and working ethic, motivation, nutrient and health, income level, social assurance, environment and working atmosphere, industrial relationship and technology, production medium, management, achievement opportunity and government policy in field of production, investation, license, tecnology, monetery, fiscal, price, distribution etc.

Through employee development it is hoped that it can be overcome by the best way. It can be said because the purpose or benefit of development can support advanced company. The 
purpose/ benefit of development is to increase knowledge especially last invention in science field, for example: the best and last principes and philosophy, to increase and to improve long implementation way, to change attitude based on new condition and to increase and to improve wage/service achieved by organization of working place, the other way employee or labor that has been developed and implement all developed program given by company well and placed rightlt. This will improve desire and working achievement of employee.

\section{REVIEW OF LITERATURE}

\section{Definition of Employee Development}

In getting the employee complying the need, a company does not only select employees well, place good field with owned skill and knowledge, but also a company pays attention self development and ability in implementing job. Developed skill is needed to be balance technology and science or economic development happening in or out compan. To obtain desired skill increase, it is better employee is given apportunity to develop science by giving chance to carry out job an carrier as early as possible by company. It is not only for increasing employee's skill, but also for changing employee's behaviour to be better. The definition and development are every effort to improve job implementation either now or future by giving information, attitude influence or adding skill. Developed programs that are planned will give benefits to organization such as productivity raising, moral raising, cost decrease, stability and flexibility of organization that is bigger to adjust to changed external. The programs will help individual needs in looking for job and meaningful for his/her carrier for a lifetime.

The other words, development is every activity that is tended to add knowledge and skill and to change attitude and behaviour. The development is as a change of someone to be more effective in working.

The implementation of employee or labor development can be implemented in three ways:

1. Through education and practice

2. Through position rise

3. Through mutation

The reasons of making mutation are:

a. There is less productive employee or does not develop on part of company.

That less productive employee or does not develop on part of company does not mean that the employee can not develop or be productive on part of the other field in a company.

b. Avoiding bored and monotonous working.

Employee as human being has bored especially for constant, monotonous and not various job. If bore has come to employee, it will impact to quality job that is done is not perfect anymore with decided standard. The solution is by giving rest and displace it to the other part.

c. Job that is not appropriate based on employee's personal. 
In fact a employee does not have seriousness or attention in working, it is not because of bored, but it is not appropriate to his/her personal. It will be bad impact to organization especially to him/herself in working needing carefulness, vigilance, and diligence. Therefore mutation is needed for employee that is appropriate to capability, skill, experience, education, responsible and other rules and reguation.

d. The employee increment on some organizations.

It will have impact overbalance of employee in one party and leck of employee in the other party. For overcoming that case mutation is needed as employee development, so the function of the exist employee will be achieved as maximal as possible, in implementing it needs objective, honest, right and careful.

e. Can not cooperate with a group in an organization

To overcome this case, it needs to do mutation to the employee to the appropriate group. Because of team work or good cooperation, working result can be achieved optimally.

f. To decrease mutation of skillful and potential employee

g. To create working distribution on using of things, money, working equipment effectively, so high productivity is created.

h. As prepration to make assessment and consideration for employee on working result on organization deciding in providing high position.

\section{The Principles of Employee Development}

In choosing a system of employee development, we must hold on to principles of employee development, so the train implementation can function effectively and efficiently. Based on research result, various principles can be proposed as guidance in improving skill, knowledge and attitude of employee.

There are some guidances, namely:

a. Motivation

Higher motivation of employee is, faster s/he will study the skill. Training as a tool must be connected to objective obtained by the employee.

b. Progress Report

Progress report is needed to know how far an employee has new knowledge, but it is not needed by report.

c. Reinforcement

If a type of skill is being studied, studying process needs to be strengthened by reward or punishment. Manager must carry on, so every reward is related to employee's progress or achievement.

d. Practice

Practicing what is studied is the important thing. It is better employee trained can 
practice the skill on the real condition.

e. Individual difference

Although group training has economical surplus, it needs to be realised that the essence the employee is diffirent one another. That is why the effective training must adjust difficulty with ability of each people.

\section{The Benefit of Employee Development}

To achieve effective and efficient emloyee, it is influenced by employee development system used by a company or organization in achieving the goal.

If employee is executed perfectly, education and training are needed either new employee or old employee. For new employee, education and training are very needed, so they know and have skill in implementing duty given by company to them. For old employee, they adjust to their more and more development duty, for example, the development in using up date equipment and technology or to adjust themselves to new employee while the employees are promoted on the higher position. Education owned by employee will encourage the employee to work hard, if employees have known their duty and responsible, they will try to achieve to higher moral.

New problems, new equipments, new knowledge, and new position will be always exist in an organization. This case is new income for manager facing change. The changes are exist because of environment according to Jhon Soeprihanto as follows:

a.The change of company's goal

b. The change of factors influencing goal's achievement

c.The change of reality being always exist as combination of two changes above

d.The change in a company:

-Production change

-Technology change

-Employee change

-Organizational environment change of company

From dynamic, complex change an continuity, it is clear that a company does not have the other alternative, except it must conduct investation in human invesment.

\section{METHODOLOGY}

\section{Short History of Company}

Fa.P.M.H.(Firma Persatuan Motor Horas) is a company in field of transportation service located on Sisingamangaraja street Km.6,3 Number 40 Medan. This company is built based on certificate number 4, January 51961 with notary Renatus Lumban Raja. This certificate is 
updated and now it stands based on certificate of number 16, january 201994 by S.M.Sinaga as notary. While it stands, this company serve transport stripe Pematang Siantar-Prapat (round trip) and Prapat-Medan (round trip). Since 1988 till right now Fa.P.M.II.(Firma Persatuan Motor Horas) serves transport stripe Medan-Pekan Baru (round trip), Medan-Jakarta (round trip), Medan-Dumai(round trip), Medan-P.Siantar (round trip), Medan-Prapat(round trip), P.Siantar- Dumai(round trip),P.Siantar-Pekan Baru(round trip), Medan-Kerinci(round trip).

\section{Organizational Structure of Company}

Every company constructed has a definite goal is to obtain optimal benefit and ability to develop. To obtain the goal, guided activity is needed in helping continuity of activities in a company and facilitate employee in implementing duty and responsible, so organizational structure is described in schematic, relation benteen superior and subordinate in achieving a goal. Organizational structure is arranged by need and condition of the company. Therefore it must be flexible, so every activity related to the interest of company can run perfectly, effectively and efficiently and can be changed if it needs, and does not change the decided purpose previously. With organizational structure of good company, every employee will know clearly what will be their duty and who will be superior or subordinate.

\section{Duty and Responsible Division}

A company that has developed has large working field. Various and types of duty need the best duty division. This duty can describe one's responsible in implementing duty in the best ways. Here, the researcher will describe duty and responsible division of every member of Fa.P.M.H (Firma Persatuan Motor Horas) namely commissioner council.

Commissioner council has duty and responsible as follows:

a. Oversee and provide advice and guidance to director in running a company.

b. Decide big line of company's policy (director)

Director has duty and responsible as follows:

a. Run a company as good as possible

b. Present a company either in or out of company

c. Provide a report to commissioner council and has a duty to lead head field to run personnel's company.

The main duty of personnel field is employee's case including employee acceptance, organizational company plan, arranging system, acceptance procedure, employee stoppage, working schedule making, salary list mking, implementing training program of employee and others related to employee's prosperity and solve dispute. Marketing field has duty and authority such as:

a. carrying out marketing

b. selling ticket in each counter and accept ticket order of passanger candidate. 
International Journal of Business and Management Review

Vol.6, No.3, pp.91-100, April 2018

Published by European Centre for Research Training and Development UK (www.eajournals.org)

c. oversee ticket field

Finances field has duty and authority as follows:

a. responsible of all activities related to either income and outcome or fund provision in running company activity including budget, cost analyzing and credit from bank

b. handle active purchsing that happens generally by director's agreement.

c. analyse and interprete accepted data from subordinate field.

Finance field in this case is divided into two:

\section{Accountancy}

This part consists of a head of accountancy helped by an assisstant, that has duty:

to take note, based on transaction proof collected by posting (displacement to big book) and to arrange finance report such as pair of scales, benefit/loss report, the head of accountancy is responsible to finance report presented to director and make report of daily cash and last month.

\section{Cashier}

In this case cashier has duty and responsible to:

* Every income and outcome of an company is in form of cash or check

* Accepted money everyday is defecated to bank to be kept. Transaction proof is deposit proof kept to accountancy. Cashier is lso responsible in managing small cash that has small relative number.

* Every income and outcome of a company must be signatured by cashier, especialy agreed by the head of accountancy. If total of outcome exceed authority limit of the head of accountancy, it must be agreed by director.

This part has duty and responsible as follows:

a. purchasing of needed spare part based on accepted order

b. purchasing of ribbon

\section{Employee's Search and Composition}

Fa.P.M.H (Firma Persatuan Motor Floras) Medan decides characteristics or features of employee needed, numbers and education level owned by employee and company tries to obtain employee or labor that is needed. Therefore a company tries to get the right employee both quality side and quantity side.Obtaining employee can not be ignored, if it is not paid attention, this case can cause employee obtained is not appropriate. If this case happends, Fa.P.M.H.(Firma Persatuan Motor Horas) Medan will be less effective nd efficient in running activity impcating financial loss for company. If this happens, job wil be less smooth and it causes wasting and the other impact causes effectivity efficiency less of being decided. Fa.P.M.H.(Firma Persatuan Motor Horas) Medan in obtaining employee that has good quality and the appropriate number needs good knowledge about labor resource where this case is

ISSN: 2052-6393(Print), ISSN: 2052-6407(Online) 
International Journal of Business and Management Review

Vol.6, No.3, pp.91-100, April 2018

Published by European Centre for Research Training and Development UK (www.eajournals.org)

hoped that effectivity and efficiency to obtain employee can be improved because with knowledge, we can know the appropriate source.

\section{Selection Process of Employee}

In selecting employee, it must be known first about the employee. Employee acceptance is generally based on need happening every year. As prerequisites:

. Education

. Working Experience

. Skill

. Physical

Based on the prerequistes above, there is lack of employee that is accepted by company that does not have appropriate education, but have good working experience, in employee acceptance of Fa.P.M.H(Firma Persatuan Motor Horas) Medan, it has priority employee that come from friends and family. Every candidate must attach:

- application letter

- curriculum vitae: especially for having working experience

- Statement letter of good behaviour from authority party

The basics in implementing selection are:

a. Selection holds on the most effective and efficient economic motif, for example, low cost to get labor.

b. A company decides absolute requisite that must be run to hold certain position

To implement selection, it needs the appropriate method for selector, in this case that is followed by leadership of company is method:

1. There is agreement of employee candidate acceptance from company leader

2. Selection to application letter conducted by company leader

3. Applicant that fulfill requisite is sent calling letter to follow interview

4. Applicant that is asserted pass of interviewing is called to follow test. If applicant passes in test, s/he will be accepted as employee in a company.

A company in accepting employee through employee relation, then employees have generally family bond one another. The implementation of selection on this company uses equipment, writing of application form, interview and test.

\section{Process of Employee Placement}

In achieving the principles of "the right man on the right place", placement case of employee is factor that very need to be paid attention in achieving company's goal. Mistake in placement 
of employee can be completed or conducted well. Basically placement process must be able to be conducted based on procedure, so the hoped employee is obtained. Therefore placing employee must be considered wisely, level of eduction, skill and competence owned by employee is appropriate of position or job that will be executed. From number of employees, this company is not too big where the company has many employees and large area.

\section{DISCUSSION}

As being described on previous chapters about employee development to working achievement of employement of Fa.P.M.H.(Firma Persatuan Motor Floras), researcher tries to present analysis and evaluation on duty division, strip and method of employee development and employee development to working achievement.

\section{Duty division}

In an organization, there are working division on every unit or organizational members, so there is tendency of strength to self separation from main. Every unit that has duty only gives attention on duty of each unit. On Fa.P.M.H.(Firma Persatuan Motor Floras), working coordination is less, that can be seen on report making, either from every part or sub part and small units in the company. The thing can be seen on the table that shows the existance of job that can not be completed and this is because the duty given to employees is special. Duty will create coordination on each part, so duty can run well because each employee can give attention fully on his/her job. From the explanation above, coordination of duty on Fa.P.M.H.(Firma Persatuan Motor Horas) Medan must be paid attention in improving employee's working achievement and achieve the company's goal. Without good coordination, the possibility of activity implementation will experience obstacles, so what the main purpose of organization can be achieved.

\section{Stripe and Method of Employee Development}

Stripe and method applied on Fa.P.M.H.(Firma Persatuan Motor Horas) is development stripe of managerial worker. This is very right, so it is looked clearly limition between operational labor and managerial labor. On managerial stripe discussed is management, for example how to motivate operational labor, so they work what is decided while operational stripe discussed is operational techniques in implementing their duty. Applied stripe and method are good enough, but it is more improved especially on operational stripe because many company activities are conducted in operational field and participant number following development program is more improved.

\section{The Influence of Employee Development to Working Achievement}

By implementing employee development of Fa.P.M.M.(Firma Persatuan Motor Horas) Medan, working achievement increases, this thing can be caused because:
a. Method of used employee development is right
b. Time training is enough
c. Employee goal is right 
International Journal of Business and Management Review

Vol.6, No.3, pp.91-100, April 2018

Published by European Centre for Research Training and Development UK (www.eajournals.org)

Unfortunately working achievement increases but it is not maximal, so the decided target is not achieved. The other side, position rotation system is seldom conducted. Rotation system is conducted right because employee works on one limit only and this case takes place in long time, owned skill is limited and can causebored. This impacts working achievement decreasing.

If employee is developed, the employee will have enough knowledge and skill to be applied on each field and part.

\section{Coordination of Duty Division}

In an organization, there is duty division on each unit or organizational members, so there is tendency to seperate self from the head. Every unit that has duties based on decision tends only paying attention to each duties. Therefore each unit is back to organizational mother in obtaining organizational goal whole because unity and organizational members are needed. Finally employee can provide maximal contribution of organizational effort. That is why coordination is needed. On Fa.P.M.H.(Firma Persatuan Motor Horas) Medan, less working coordination can be seen in making report either from every part or sub part and small units in an company. The other side, coordination can be seen in working plan. Intens coordination of Fa.P.M.H. is less of the other instantion for example between the government and regional governmenr in providing subsidy, protection license etc.

\section{CONCLUSION}

After the researcher obtains, collects and analyzes data and finds research result as that has been described on previous chapters, researcher takes conclusion as follows:

Basically Fa.P.M.H. Medan has run the development or education and train, but the number of developed employee is few. In participant selection of employee development, company is less objective. The development of employee's achievement in facing the obstacle is many employees that have followed education and train placed in good place and less in getting company's appreciation.

\section{REFERENCES}

Dharma, Agus, Manajemen Prestasi Keria, CV.Rajawali, Jakarta, 1985

Drucker,Peter F., Manajemen Tugas Tanggung Jawab Praktek. Seri Manajemen No.36a, Cetakan Ketiga,LPPM, Jakarta, 1982

F'lippo, Edwin B., Manajemen Personalia. Alih bahasa, M.Masud, Edisi Keempat, Erlangga , Jakarta, 1991

Handoko , T.Hani, Manajemen Personalia dan Sumber Daya Manusia. Cetakan Pertama, Liberty, Yogyakarta, 1985

Had i poerwo, Bambang, Meningkatkan Produktivitas Karyawan. Cetakan Keempat, Jembatan .Jakarta, 1979

Hadipoerwo. Tata Personalia. Cetakan Kelima, Jembatan, Jakarta, 1982

Kertonegoro,Sentanoe, Prinsip dan Teknik Manajemen. Cetakan Kedua, Ananda, Yogyakarta, 1985 
International Journal of Business and Management Review Vol.6, No.3, pp.91-100, April 2018 _ Published by European Centre for Research Training and Development UK (www.eajournals.org)

Moekijat. Perencanaan Tenaga Kerja, Cetakan Ketiga, Pioner Jaya, Bandung, 1988

Munir, A.S., Pendekatan Manusia dan Organisasi Terhadap Pembinaan Kepegawaian, Cetakan Pertama, PT.Gunung Agung, Jakarta, 1984

Musanef. Manajemen Kepegawaian Indonesia. Edisi Revisi Pertama, PT.Gunung Agung, Jakarta, 1986

Nitisemito Alex.S.. Manajemen Personalia, Edisi Revisi Pertama, ghalia Indonesia, Jakarta, 1982

Simanjuntak ;APU,Payaman Dr., Manajemen Sumber Daya Manusia, Jakarta, 1994 